\title{
PROVENANCE STUDY ON A SMALL SELECTION OF ROMAN POTSHARDS \\ (TĂŞNAD-SERE SITE, SATU MARE COUNTY, ROMANIA). 1.
}

\section{ENIKŐ BITAYa, BERNADETH KISS-PATAKI ${ }^{b}$, GYÖRGY SZAKMÁNYc, EMIL INDREA $^{\mathrm{d}}$, IRÉN KACSÓd, IOAN BRATU ${ }^{\mathrm{d}}$, ERZSÉBET VERESS ${ }^{\circ}$}

\begin{abstract}
Five representative potshards collected from the Tăşnad-Sere C 52 archaeological site were investigated in order to evaluate the occurring differences of the raw materials used and the technology applied. The structural and compositional differences shown by petrographic analysis (optical microscopy /OM/ and XRD) and FTIR spectroscopy data indicate that according to both the raw materials composition (clay sediments and temper) and the pottery technique the samples studied form two distinct groups.
\end{abstract}

Keywords: ancient ceramics, provenance, optical microscopy, PXRD, FTIR spectroscopy

\section{INTRODUCTION}

Correct archaeological conclusions require, besides the typological characterization of the archaeological findings unearthed at a certain site, their complex archaeometric (structural, compositional and technological) characterization. The possible source of the raw materials used and the

a Sapientia Hungarian University of Transylvania, Faculty of Technical and Human Sciences, OP 9 CP 4, RO-540485 Targu-Mures, Romania, ebitay@ms.sapientia.ro

b Bosch Group in Hungary, Postbox 331, H-1475 Budapest Hungary, bernadethpataki@gmail.com

c Eötvös Loránd University, Institute of Geography and Earth Sciences, Pázmány Péter allée 1/C, H-1117 Budapest, Hungary

d National Institute for Research and Developement of Isotopic and Molecular Technologies, Donath Str. 65-103, RO-400293 Cluj, Romania.

e Transylvanian Museum Society, Napoca Str. 2-4, RO-400750 Cluj, Romania, veresserzsebet@gmail.com 
technical peculiarities together could confirm some of the archaeologist's technology-related suppositions and answer some of the questions related to the dynamics of local or regional trade. [1]

Archaeometric characterization of ceramic vestiges usually is carried out on large sample populations, concluding in the end on the basis of statistical analysis of the experimental data obtained. However, the quantity of the available samples sometimes is strongly limited. This study tries to evaluate the efficiency and reliability of the most frequently applied analytical methods in case of a few-numbered selection of ancient ceramic samples. Five potshard samples collected from the same archaeological site (Tăşnad-Sere, one of the Complex 52 dwellings) were investigated in order to establish their differences by the most traditional mineralogical analyses (polarized optical microscopy (OM), powder X-ray diffraction (PXRD) analysis and Fourier transformed (FTIR) spectroscopy).

\section{ARCHAEOLOGICAL CONTEXT}

Tăşnad is located in Satu-Mare County, NW Romania, on one of the main geothermal areas of the country. The settlement and its surroundings are provenly continuously inhabited at least since the Neolithic Age, their Starčevo-Criş and Coţofeni type finds being among the most important ones from the area. The stratigraphy of the location shows generally an approx. $0.30 \mathrm{~m}$ thick vegetal soil layer followed in-depth by a $0.30-0.80 \mathrm{~m}$ grayish-black culture layer containing an impressive quantity of ceramic remains, mostly Starčevo-Criş IIIB-IVA dated shards [2-5]

The Tăşnad-Sere location was necessarily opened to rescue archaeology by reason of the developments effectuated on the neighbouring thermal baths, Tăşnad-Strand (Figure 1).

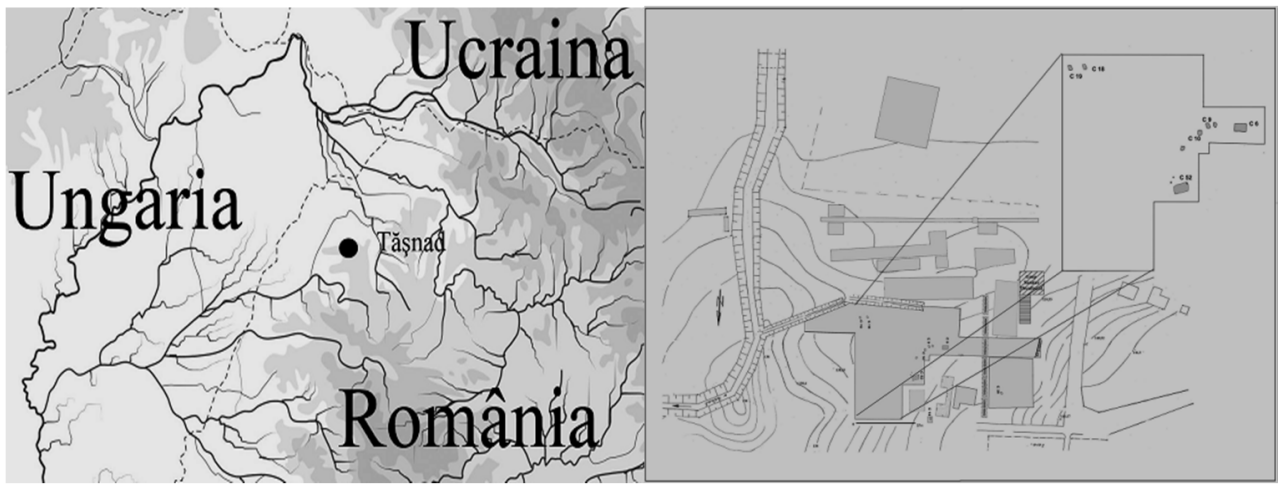

Figure 1. Location of the Tăşnad Sere archaeological site. 
On the site excavated during eight salvage campaigns between 1989 and 2006 more than 100 archaeological complexes were discovered: (dwellings, huts, pits, graves, ditches), each holding varied materials (fine pottery, stone pieces, terracotta figurines, animal bones). The complexes unearthed were mostly Neolithic, however, ten Roman sites dating from the 2nd and 3rd centuries AD (three of them without any material remains) were also found. Although the Roman ceramic material is significantly less, they are of great relevancy, being the first such discovery in the area in archaeological context [5-7].

The five Roman-period potshards selected as representative samples for the present study turned up in each others' close vicinity from one dwelling of Complex 52 (C52), the richest of the sites, and cover the main Roman-period pottery types found at the site.

\section{RESULTS AND DISCUSSION}

\section{Macroscopic and microscopic characterization}

The specimens selected for this study are representative pot fragments covering the main pottery types found at the site (Figure 2).

Their first grouping was provided by their macroscopic features (Table1): color and homogeneity of the ceramic body, the visible porosity and inclusions (type, shape, dimension, relative distribution, orientation) and the occurrent technological failures or deviations (signs of incomplete firing or over-firing, cracks).

\begin{tabular}{|c|c|c|c|c|c|}
\hline Sample & $5-2-1$ & $5-2-2$ & $5-2-3$ & $5-2-4$ & $5-2-5$ \\
\hline $\begin{array}{c}\text { Outer } \\
\text { surface }\end{array}$ & & & & & \\
\hline $\begin{array}{c}\text { Inner } \\
\text { surface }\end{array}$ & & & & & \\
\hline Core & & & & & \\
\hline
\end{tabular}

Figure 2. Macroscopic aspect of the shards selected for characterization. 
Sample 5-2-1, a hand-made coarse ceramic tempered with rock fragments and grog (ceramic debris) represents statistically approximately $23 \%$ of the total of findings. It is dark grey, on the outside being covered with a "rusty" crust while on the inner side appears a white, carbonated deposit; most probably both of depositional origin. The homogeneous sample body is moderately porous. Sample 5-2-2 (16\%) is potter's wheel worked from a coarse ceramic paste containing many inclusions of quartzitic sand (naturally tempered?). This shard is sandwich structured with grayish core grading into light reddish-brown zones towards the margins. The wheel-modelled fine ware type sample 5-2-3 $(13 \%)$ has homogeneous, uniformly light grey body with approximately plan parallel smooth surfaces.

Shards coded 5-2-4 and 5-2-5 are unique as type. The most porous, slightly cracked, brownish-grey sample 5-2-4 is worked on the potter's wheel from fine ceramic paste and holds a stamped sign on the outside. Sample 5-2-5 is part of a wheel thrown, black painted fine ware with homogeneous grey body; its blackish interior presents stress cracks.

Table 1. Macroscopic features of the samples.

\begin{tabular}{|c|c|c|c|c|}
\hline \multicolumn{2}{|c|}{ Sample } & \multicolumn{3}{c|}{ Macroscopic features } \\
\hline Code & No. & Color & $\begin{array}{c}\text { Paste } \\
\text { appearance }\end{array}$ & $\begin{array}{c}\text { Inclusions, } \\
\text { pores }\end{array}$ \\
\hline $5-2-1$ & 49345 & dark grey & coarse & moderately porous \\
\hline $5-2-2$ & 49333 & $\begin{array}{c}\text { sandwich, greyish core, } \\
\text { reddish-brown margins }\end{array}$ & coarse & many inclusions \\
\hline $5-2-3$ & 49301 & light grey & fine & - \\
\hline $5-2-4$ & 49275 & greyish-brown, stamped & fine & porous \\
\hline $5-2-5$ & 49278 & light grey, ornamented & fine & stress cracks inside \\
\hline
\end{tabular}

Shards coded 5-2-4 and 5-2-5 are unique as type. The most porous, slightly cracked, brownish-grey sample 5-2-4 is worked on the potter's wheel from fine ceramic paste and holds a stamped sign on the outside. Sample 5-2-5 is part of a wheel thrown, black painted fine ware with homogeneous grey body; its blackish interior presents stress cracks. 
Microscopic characteristics of the samples are presented by Figure 3 and Table 2.

The 5-2-1 sample has hiatal fabric with anisotropic matrix and many non plastic constituents: mostly monocrystalline quartz associated with some polycrystalline quartz presenting sutured contacts of the individual grains, chert, even a little amount of glass. The argillaceous rock fragments (ARF) in the clayish matrix indicate the use of a clay mixture for the ceramic paste. The sample show limonitic concretions and a grog inclusion with concentric appearance due to the occurred natural transformations and inhomogeneous mixing. This and the anisotropic matrix lead to the conclusion that the possible firing temperature was quite low.

Sample 5-2-2 also has hiatal fabric and presents the same anisotropy characteristics. The identified coarse grain fragments allow a temper grouping. The first group is formed by monocrystalline quartz with strong wavy extinction, moreover strongly oriented quartzite and micaceous quartzite, probably of crystalline metamorphic schist origin. Granitoid fragments and individual K-feldspars are also present. The second group contains vulcanite fragments with plagioclase phenocrysts. Individually broken, zoned plagioclases and weakly altered green amphibole clasts may also originate from the vulcanite. In the vulcanite fragments (and only there) occur a few weakly altered Individual biotite grains; epidote-zoisite grains and rutile are also present as accessories. Fine grained sericite-muscovite minerals are present in the groundmass. Opaque minerals with an isometric appearance (possibly magnetite) occur perhaps as a result of the firing process; isotropic clasts, most probably glass fragments can be observed too. The presence of ARFs with some altered rock fragments and limonitichematitic nodules lead to the consideration that the raw material used was a clay mixture.

The last three samples are very similar from the point of view of their production technology which employed a higher firing temperature. They are not presenting downright coarse grain sizes except of 5-2-4.

In case of sample 5-2-3 the largest amount of the non plastic inclusions is constituted by monocrystalline quartz with wavy extinction. Polycrystalline quartz grains are also present, suggesting a metamorphic origin. K-feldspars and plagioclases are present only in a few amounts. Occasionally normal extinction monocrystalline quartz of volcanic origin also occurs, as well as a few amounts of parallel oriented sericite-muscovite. 


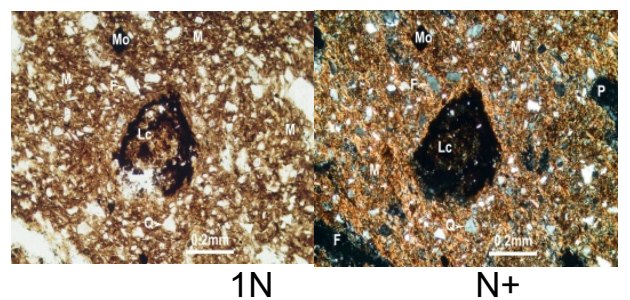

$1 \mathrm{~N}$

5.2 .1 (coarse)

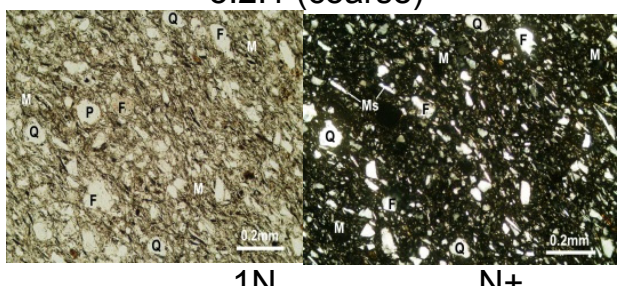

5.2.3 (semifine)

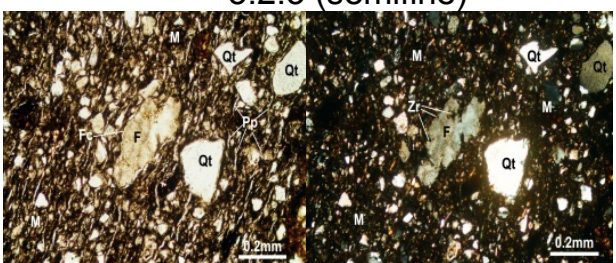

$1 \mathrm{~N}$
$\mathrm{N}+$

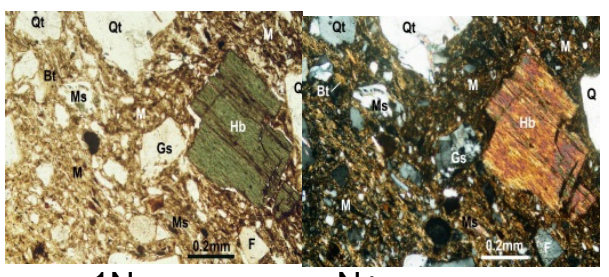

$1 \mathrm{~N}$

5.2 .2 (coarse)

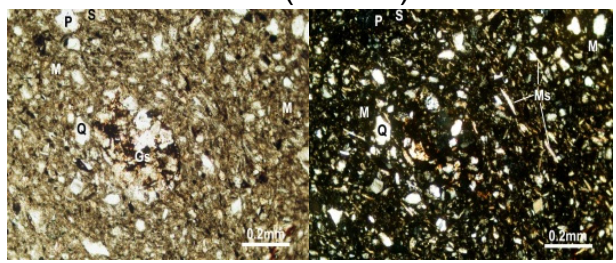

$1 \mathrm{~N}$

5.2 .5 (fine)

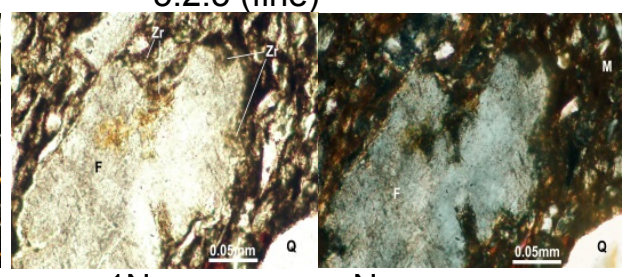

$1 \mathrm{~N}$
$\mathrm{N}+$

$\mathrm{N}+$

5.2.4 (semicoarse)

5.2.4 clear evidence of the melting zone

Figure 3. OM petrographic characteristics of the ceramic samples.

Microphotos of thin sections with single nicol $(1 \mathrm{~N})$ and crossed nicols $(\mathrm{N}+)$ M: matrix, Q: quartz, Qt: quartzite, Hb: hornblende, F: feldspar, Ms: muscovite,

Bt: biotite, Gs: gneiss, P: pore, Pp: primary pore, Zr: reaction zone

The large amount of finely grained isometric opaque mineral occurring is probably magnetite formed during firing. The possible raw material in this case too was a mixture of levigated clays.

Characterization of sample 5-2-5 roughly follows that of sample 5-23 , evidencing a series of common features.

Sample 5-2-5, as compared to 5-2-3 is finer and more oriented. It contains a large amount of monocrystalline quartz with both wavy and normal extinction; occasionally K-feldspars occur. The very rare occurrence of zoned plagioclases might indicate a volcanic origin. The sample contains a little more of fine flakes of micas in forms of sericites-muscovites with parallel orientation. Large amount of isometric opaque minerals (magnetite) are also present due to the firing process. The ARFs are dark brown. All these features lead to the consideration that it was made by another clay type or the raw material was better mixed. 
Table 2. Mineralogic-petrographic characterization of the ceramics.

\begin{tabular}{|c|c|c|c|c|c|}
\hline \multirow{2}{*}{ Property } & \multicolumn{5}{|c|}{ Sample } \\
\hline & 5.2.1 & 5.2 .2 & 5.2 .3 & 5.2 .4 & 5.2 .5 \\
\hline Paste & coarse & coarse & semifine & semicoarse & fine \\
\hline $\begin{array}{l}\text { Grain size } \\
\text { distrib. }\end{array}$ & $\begin{array}{l}18 \% \mathrm{R} \\
36 \% \mathrm{~A} \\
46 \% \mathrm{~L}:\end{array}$ & $\begin{array}{l}24 \% \mathrm{R} \\
35 \% \mathrm{~A} \\
41 \% \mathrm{~L} \\
\end{array}$ & $\begin{array}{c}8 \% \mathrm{R} \\
35 \% \mathrm{~A} \\
57 \% \mathrm{~L}:\end{array}$ & $\begin{array}{l}12 \% \mathrm{R} \\
35 \% \mathrm{~A} \\
53 \% \mathrm{~L}:\end{array}$ & $\begin{array}{l}4 \% \mathrm{R} \\
36 \% \mathrm{~A} \\
60 \% \mathrm{~L}:\end{array}$ \\
\hline Matrix & $\begin{array}{c}\text { surface layer: } \\
\text { microcryst.- } \\
\text { amorphous; } \\
\text { core: } \\
\text { amorphous- } \\
\text { microcryst. }\end{array}$ & $\begin{array}{c}\text {-sandwich } \\
\text { structure; } \\
\text {-core:black, } \\
\text { amorphous; } \\
\text {-ext. layers: } \\
\text { brownish- } \\
\text { red, cryst.; } \\
\text {-intermed.: } \\
\text { microcryst.- } \\
\text { amorphous. }\end{array}$ & amorphous & amorphous & amorphous \\
\hline Texture & $\begin{array}{l}\text { mostly oriented; } \\
\text { homogeneous, } \\
\text { elongated } \\
\text { primary pores }\end{array}$ & oriented & $\begin{array}{c}\text { oriented; } \\
\text { primary and } \\
\text { secondary } \\
\text { pores }\end{array}$ & $\begin{array}{l}\text { oriented; } \\
\text { many } \\
\text { elongated } \\
\text { pores and } \\
\text { contraction } \\
\text { cracks } \\
\end{array}$ & $\begin{array}{c}\text { weakly } \\
\text { oriented; } \\
\text { secondary } \\
\text { pores, } \\
\text { contraction } \\
\text { cracks } \\
\end{array}$ \\
\hline Clasts & $\begin{array}{l}\text { ceramoclasts, } \\
\text { lithoclasts, } \\
\text { crystalloclasts }\end{array}$ & \multicolumn{4}{|c|}{ lithoclasts, crystalloclasts } \\
\hline $\begin{array}{c}\text { OM } \\
\text { identified } \\
\text { main } \\
\text { minerals }\end{array}$ & $\begin{array}{l}\text { quartz, quartzite } \\
\text { feldspar } \\
\text { muscovite } \\
\text { biotite } \\
\text { hornblende } \\
\text { zircon } \\
\text { hematite } \\
\text { montmorillonite }\end{array}$ & $\begin{array}{c}\text { quartz, } \\
\text { quartzite } \\
\text { feldspar } \\
\text { hornblende } \\
\text { muscovite } \\
\text { biotite } \\
\text { pyroxene } \\
\text { titanite } \\
\text { gneiss } \\
\text { hematite } \\
\text { zircon } \\
\text { rutile }\end{array}$ & $\begin{array}{l}\text { quartz, } \\
\text { quartzite } \\
\text { feldspar } \\
\text { muscovite } \\
\text { biotite } \\
\text { hematite } \\
\text { zircon } \\
\text { rutile }\end{array}$ & $\begin{array}{l}\text { quartz, } \\
\text { quartzite } \\
\text { feldspar } \\
\text { muscovite } \\
\text { biotite } \\
\text { hornblende } \\
\text { rutile } \\
\text { staurolite }\end{array}$ & $\begin{array}{l}\text { quartz, } \\
\text { quartzite } \\
\text { feldspar } \\
\text { muscovite } \\
\text { biotite } \\
\text { gneiss }\end{array}$ \\
\hline $\begin{array}{l}\text { Grain size } \\
\text { distrib.* }\end{array}$ & $\begin{array}{l}18 \% \mathrm{R} \\
36 \% \mathrm{~A} \\
46 \% \mathrm{~L}:\end{array}$ & $\begin{array}{l}24 \% \mathrm{R} \\
35 \% \mathrm{~A} \\
41 \% \mathrm{~L} \\
\end{array}$ & $\begin{array}{l}8 \% \mathrm{R} \\
35 \% \mathrm{~A} \\
57 \% \mathrm{~L}:\end{array}$ & $\begin{array}{l}12 \% \mathrm{R} \\
35 \% \mathrm{~A} \\
53 \% \mathrm{~L}:\end{array}$ & $\begin{array}{l}4 \% \mathrm{R} \\
36 \% \mathrm{~A} \\
60 \% \mathrm{~L}:\end{array}$ \\
\hline $\begin{array}{l}\text { Firing } \\
\text { temp. }\end{array}$ & $800-850^{\circ} \mathrm{C}$ & $\approx 850^{\circ} \mathrm{C}$ & $\approx 1000^{\circ} \mathrm{C}$ & $950-100{ }^{\circ} \mathrm{C}$ & $>950^{\circ} \mathrm{C}$ \\
\hline
\end{tabular}

* R: rudite /pebble/ (mean diameter $\left.d_{R}>1 \mathrm{~mm}\right)$; A: arenite /sand/ $\left(1 \mathrm{~mm}>\mathrm{d}_{\mathrm{A}}>\right.$ $0.0625 \mathrm{~mm})$; L: lutite $/ \mathrm{silt}, \mathrm{mud} /\left(\mathrm{d}_{\mathrm{L}}<0.0625 \mathrm{~mm}\right)$ [8] 
The presence of well classified, fine grained non plastic inclusions in samples 5-2-3 and 5-2-5 suggests that in this case the raw material should be naturally tempered and the clay was levigated, whilst in case of samples 5-2-1 and 5-2-2 a deliberate tempered raw material was used, allowing to classify the investigated samples into two groups.

The 5-2-4 sample stands for a transition group between the two previously mentioned being closer to the second one concerning the production technique, the composition and its hiatal fabrics. The production technique seems to imply a higher firing temperature. The raw material was tempered with coarser grained clasts of vulcanite and crystalline schist origin, similarly to sample 5-2-2, containing, in comparison, a larger amount of polycrystalline quartz and micaceous quartzite and less of vulcanites. Additionally, there are a few plagioclases, K-feldspars, green amphiboles; which one's limonitic concretions and textural features allow the supposition of their clayish origin. Clinozoisite also appears as accessory mineral. The sample contains opaque minerals as 5-2-3 and 5-2-5 (though lesser) supposed to be mostly magnetite resulted from the firing process conducted at higher temperature, or longer time, or both, as indicated by the argillaceous rock fragments (ARF) better fired than those present in samples 5-2-1 and 5-2-2.

\section{PXRD analysis}

PXRD analysis was used as complementary petrographic method for OM. [9] Through the OM investigation the phenocrysts present in the ceramic samples could be identified, but the information hided in the groundmass have to be explored by PXRD, with the limitation that PXRD is characterized by a $5 \%$ threshold.

The results of the PXRD analysis performed on the ceramic selection investigated are presented on Figure 4 and Tables 3 and 4.

The PXRD patterns of the ceramic samples are in concordance with the optical microscopy data (Table 2). 


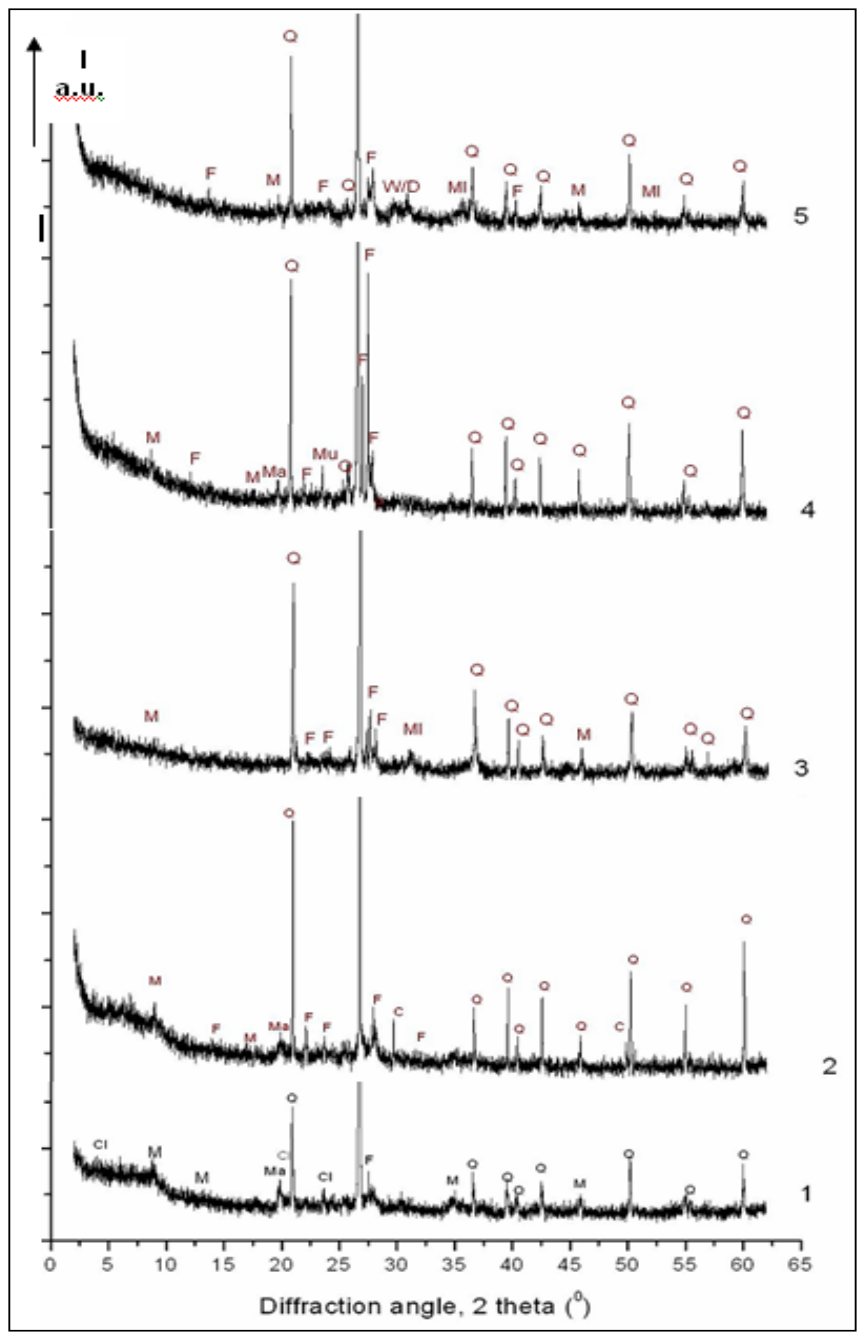

Figure 4. PXRD patterns of the investigated ceramic samples.

$\mathrm{Q}$ : quartz, quartzites - $\mathrm{SiO}_{2}$; M: micas (biotite) - $\mathrm{Mg}_{2.001} \mathrm{Al}_{1.999} \mathrm{KSi}_{3} \mathrm{O}_{12} \mathrm{H}_{2}$;

$\mathrm{Mu}$ : muscovites - $\mathrm{Al}_{1,94} \mathrm{Si}_{3,86} \mathrm{~K}_{0,86}\left(\mathrm{O}_{12} \mathrm{H}_{2}\right) ; \mathrm{Al}_{1,96} \mathrm{Si}_{3,8} \mathrm{~K}_{0,94}\left(\mathrm{O}_{12} \mathrm{H}_{2}\right)$; $\mathrm{F}$ : feldspars (mostly $\mathrm{K}$ - feldspars: orthoclase, microcline - $\mathrm{KAISi}_{3} \mathrm{O}_{8}$, possible some albite - $\mathrm{NaAlSi}_{3} \mathrm{O}_{8}$ ); $\mathrm{Cl}$ : chlorite - $(\mathrm{Mg}, \mathrm{Fe})_{3}(\mathrm{Si}, \mathrm{Al})_{4} \mathrm{O}_{10}(\mathrm{OH})_{2} \cdot(\mathrm{Mg}, \mathrm{Fe})_{3}(\mathrm{OH})_{6}$.

The high and noisy baselines of the diffractograms indicate that the samples contain a large amount of weakly crystallized material, otherwise on the diffractograms appear the same mineral phases over and over again. 
Quartzitic minerals $(Q)$ constitute the dominant mineral phase in each case. The rest of the significant diffraction lines correspond to micas, mostly biotite (Bt): $\mathrm{Mg}_{2.001} \mathrm{Al}_{1,999} \mathrm{KSi}_{3} \mathrm{O}_{12} \mathrm{H}_{2}$; K-feldspars (F) like microcline or orthoclase (Orth): $\mathrm{KAISi}_{3} \mathrm{O}_{8}$, plagioclases like albite: $\mathrm{NaAlSi}_{3} \mathrm{O}_{8}$; muscovites (Mu) of slightly different compositions like Mu2: $\mathrm{Al}_{1,94} \mathrm{Si}_{3,86} \mathrm{~K}_{0,86} \mathrm{O}_{12} \mathrm{H}_{2}$ and Mu3: $\mathrm{Al}_{1,96} \mathrm{Si}_{3,8} \mathrm{~K}_{0,94} \mathrm{O}_{12} \mathrm{H}_{2}$; finally, in case of sample 5-2-3 and 5-2-5, an reduced amount of mullite (M): $\mathrm{Al}_{6} \mathrm{Si}_{2} \mathrm{O}_{13}$ (Table 4).

Table 3. Relative intensities $I_{R}$ of the main mineral components

\begin{tabular}{|c|c|c|c|c|c|c|}
\hline \multirow{2}{*}{ Sample } & \multicolumn{7}{|c|}{ IR $_{\mathbf{R}}(\%)$} \\
& \multicolumn{7}{|c|}{} \\
\cline { 2 - 8 } & Bt & Mu2 & Mu3 & Orth & M & Q \\
\hline $5-2-1$ & 11.2 & 30.0 & - & 16.6 & - & 42.2 \\
\hline $5-2-2$ & 9.5 & 41.8 & - & 8.9 & - & 39.8 \\
\hline $5-2-3$ & 8.3 & 25.3 & 7.7 & - & 1.3 & 57.4 \\
\hline $5-2-4$ & 2.5 & 4.0 & 62.4 & - & - & 31.1 \\
\hline $5-2-5$ & 6.2 & 36.5 & 4.8 & - & 3.8 & 48.7 \\
\hline
\end{tabular}

The results of the semi-quantitative mineralogical phase analysis permitted by the diffraction data obtained on the five ceramic samples are presented in Table 4.

Table 4. Semiquantitative results of the XRD analysis.

\begin{tabular}{|c|c|c|c|c|c|c|c|}
\hline \multirow{2}{*}{ Sample } & \multicolumn{7}{|c|}{ Mineral* } \\
\hline & $\mathbf{Q}$ & $F$ & PIg & Phy & MI & Gh & $\mathbf{G}$ \\
\hline $5-2-1$ & $x X X X$ & $x$ & $x x$ & $x$ & $x$ & $X$ & \\
\hline $5-2-2$ & XXXX & $x$ & $x x$ & $x$ & & & \\
\hline $5-2-3$ & $x x x x$ & $x$ & $x x$ & & & $X$ & $x$ \\
\hline $5-2-4$ & $x x x x$ & $x x$ & $x x x$ & $x$ & $\operatorname{tr}$ & & \\
\hline $5-2-5$ & $x x x x$ & $x$ & $x x$ & & $x$ & & \\
\hline
\end{tabular}

Q: quartz; F: K-feldspars; Plg: plagioclases; Phy: "10 Á phases"; Mi: micas; Gh: gehlenite; G: goethite.

${ }^{*}$ Number of $(x)$ characterize the mineral phase abundance; tr: only traces.

The relative PXRD peak intensities of the main mineral constituents in case of the different samples (Table 3 ) as well as the variant heavy mineral contents observed in the OM study indicate that the ceramics investigated, although from the very same archaeological site, are made from raw 
materials obtained from at least three different sources. The differences of the firing mineral phases indicate different pottery technologies (different firing conditions) also.

As might be seen above, characteristically all investigated samples presented dominantly high quartz content and contained larger amounts of plagioclases than K-feldspars. Sample 5-2-4 contains some traces of mica, showing comparatively larger K-feldspar and plagioclase content, while both "10 Á phases" and micas are totally absent in case of 5-2-3 ("10 ̊̊ phases" are dehydroxylated illite-like phases formed from phyllosilicates which remain in the ceramic material after being fired at relatively low temperatures [10]).

The mineral composition of the supposed raw materials generally corresponds to that of samples 5-2-2, 5-2-3 and 5-2-4, indicating a possible local origin, however, the presence of micas in 5-2-1 and 5-2-5 denote that in these cases the green paste might be prepared using different clay(s).

Due to the very reduced quantity of the $10 \AA$ phases, the ceramics had to be fired above $700-750^{\circ} \mathrm{C}$. In samples 5-2-1 and 5-2-3 even gehlenite $\left(\mathrm{Ca}_{2} \mathrm{Al}\left[\mathrm{AISiO}{ }_{7}\right]\right)$ could be observed, which is peculiar to the fired pots (gehlenite appears at $800^{\circ} \mathrm{C}$ ). [9]

The moderate presence of $10 \AA$ phases in items 5-2-1, 5-2-2 and 52-4 could be attributed to their incipient re-hydration during the burial.

PXRD data in conjunction with the optical microscopy data allowed the identification of several thermal processes, mainly affecting the clayish matrix. The most important such processes are sintering (samples 5-2-1 and 5-2-2); formation of isotropic, amorphous and/or glassy areas in the matrix (5-2-3, 5-2-4, 5-2-5); developing of secondary pores and of stress cracks (5-2-3, 5-2-4, 5-2-5); partial decomposition of micas (5-2-3, 5-2-4, 5$2-5)$; appearance of reaction zones between the quartz clasts and matrix (especially in 5-2-4); melting of quartz rims and formation of a scalloped texture (5-2-4); finally, the almost totally lack of the small $2 \theta$ value kaolinite lines in the XRD of all ceramic samples.

On basis of these observations, the firing temperature estimated even in case of samples 5-2-1 and 5-2-2 was at least of $800^{\circ} \mathrm{C}$, while in case of samples 5-2-3, 5-2-4 and 5-2-5 a firing temperature of approximately $1000^{\circ} \mathrm{C}$ can be assumed.

\section{FTIR spectroscopy}

FTIR spectra and the resultant data are presented in the Figure 5 and 6 , and respectively in Table 5 . Absorption frequencies were assigned considering the available literature data referring to the most common clay mineral components and previous investigations carried on (mainly ancient) ceramic samples [9-19]. 


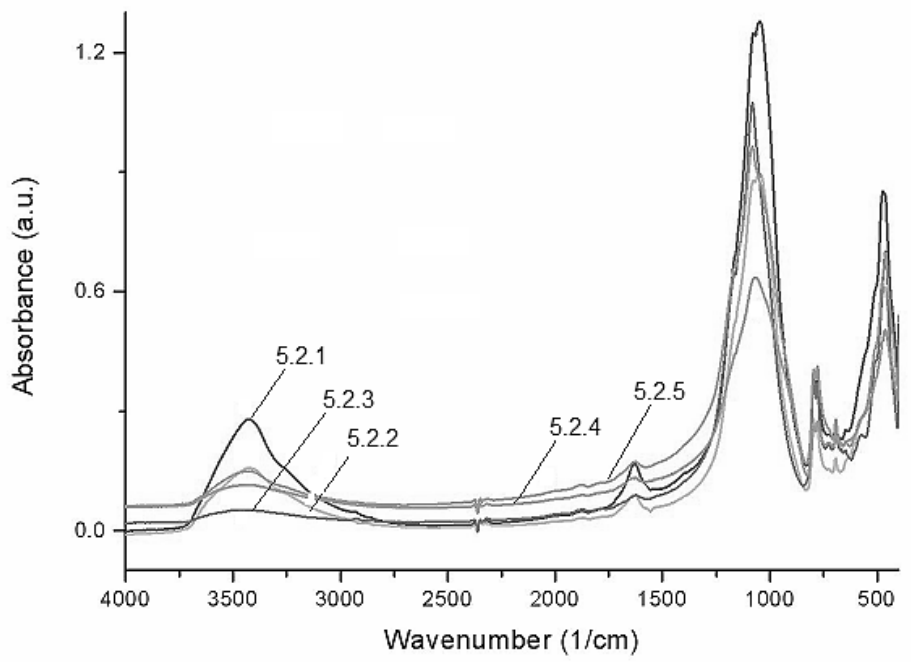

Figure 5. FTIR spectra of the ceramic samples $\left(4000-400 \mathrm{~cm}^{-1}\right)$.

Figure 6 shows in more details the absorption bands of the 1600 $400 \mathrm{~cm}^{-1}$ spectral domain (the $\mathrm{SiO} / \mathrm{AlO} / \mathrm{MeO}$ region).

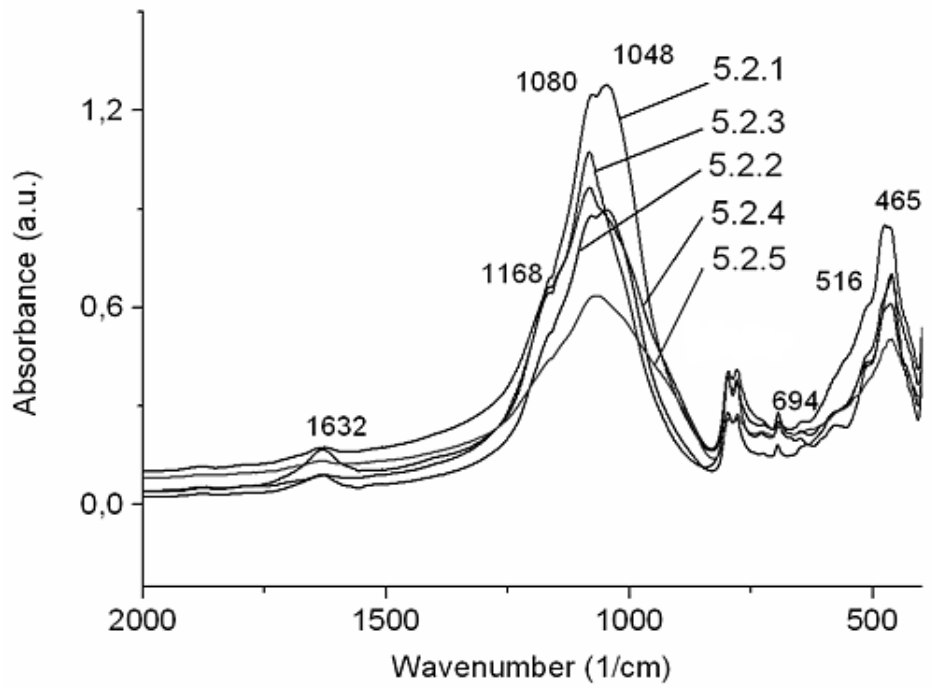

Figure 6. Extended FTIR spectra in the $\mathrm{SiO} / \mathrm{AIO} / \mathrm{MeO}$ domain. 
Table 5. Experimental absorption frequencies and their assignments. [7-12]

\begin{tabular}{|c|c|c|c|c|c|}
\hline \multicolumn{5}{|c|}{ Absorption frequencies $\left(\mathrm{cm}^{-1}\right)$} & \multirow{2}{*}{ Assignment } \\
\hline 5-2-1 & $5-2-2$ & $5-2-3$ & $5-2-4$ & 5-2-5 & \\
\hline 3429 & 3425 & 3455 & 3429 & 3439 & $\mathrm{Al}-\mathrm{O}-\mathrm{H}(\mathrm{Mo})$ \\
\hline & & & $3333 \mathrm{sh}$ & & \multirow{4}{*}{$\begin{array}{c}\mathrm{H}-\mathrm{O}-\mathrm{H} \text {, free } \mathrm{O}-\mathrm{H} \\
\text { stretch of ads. water } \\
(\mathrm{Mo}, \mathrm{Mu})\end{array}$} \\
\hline $3285 \mathrm{sh}$ & 3285 sh & & & & \\
\hline 2927 & & 2927 & 2929 & & \\
\hline 2856 & & 2857 & & & \\
\hline $1631 \mathrm{~m}$ & $1629 \mathrm{~m}$ & 1625 v.w & 1629 v.w & 1631 v.w & $\mathrm{H}-\mathrm{O}-\mathrm{H}(\mathrm{Mo})$ \\
\hline $1162 \mathrm{sh}$ & $1162 \mathrm{sh}$ & 1164 & $1166 \mathrm{sh}$ & $1164 \mathrm{sh}$ & $\begin{array}{l}\mathrm{H}-\mathrm{O}-\mathrm{H}(\mathrm{Mo}) \\
\mathrm{Si}-\mathrm{O}(\mathrm{Mu})\end{array}$ \\
\hline 1078 & 1078 & 1084 & 1082 & 1080 & Si-O (Q) \\
\hline 1048 & 1046 & & $1046 \mathrm{sh}$ & 1050 & $\begin{array}{c}\mathrm{Si}-\mathrm{O}(\mathrm{Mo}) \\
\text { Si-O-Si (Mu) }\end{array}$ \\
\hline 797 & 798 & 797 & 797 & 799 & $\begin{array}{c}\text { Si-O } \\
\text { Si-O } \perp \text { opt. axis (Q) } \\
(\mathrm{Al}, \mathrm{Mg})-\mathrm{OH}(\mathrm{Mo}) \\
\text { Si-O-Al }(\mathrm{Mu})\end{array}$ \\
\hline 780 & 778 & 780 & 778 & 780 & Si-Ollopt. axis (Q) \\
\hline 722 & 725 & 729 & $724 \mathrm{sh}$ & 723 & Si-O-Al (Mu) \\
\hline \multirow[t]{2}{*}{693} & 695 & 695 & 693 & 693 & $\begin{array}{c}\text { Si-O-Al (Mo, Mu) } \\
\text { Si-O (Q) }\end{array}$ \\
\hline & $572 \mathrm{sh}$ & 577 & $577 \mathrm{sh}$ & $575 \mathrm{sh}$ & Al-O-H (Mo) \\
\hline $553 \mathrm{sh}$ & & & & & Si-O $(\mathrm{Q}, \mathrm{Mu})$ \\
\hline $512 \mathrm{sh}$ & $510 \mathrm{sh}$ & 512 & $510 \mathrm{sh}$ & $510 \mathrm{sh}$ & Si-O (Q) \\
\hline 476 & $472 \mathrm{sh}$ & & $478 \mathrm{sh}$ & $474 \mathrm{sh}$ & $\mathrm{Si}-\mathrm{O}(\mathrm{Q}, \mathrm{Mo}, \mathrm{Mu})$ \\
\hline 465 & 461 & 461 & 461 & 463 & $\begin{array}{c}\text { Si-O }(Q, M u) \\
\text { Si-O-Mg (Mo) } \\
\end{array}$ \\
\hline $433 \mathrm{sh}$ & 431 & & & & $\mathrm{Si}-\mathrm{O}(\mathrm{Q}, \mathrm{Mo}, \mathrm{Mu})$ \\
\hline
\end{tabular}

Abbreviations: sh: shoulder, s: sharp, m: medium intensity, w: weak, $v, w$ : very weak; Q: quartz, Mo: montmorillonite, Mu: muscovite.

Infrared spectroscopy is a sensitive monitor of thermal processes (dehydration, dehydroxylation, redox transformations) occurred during the firing of clay minerals. Between $300-500^{\circ} \mathrm{C}$ the dehydroxylation of octahedral layers of most clay minerals occur, as reflected by the marked attenuation of the bands due to $\mathrm{Al}-\mathrm{OH}$ in-plane vibration at $920 \mathrm{~cm}^{-1}$ and respectively to translational vibrations involving $\mathrm{OH}$ at $522 \mathrm{~cm}^{-1}$. By attaining $600^{\circ} \mathrm{C}$ the intensity of hydroxyl bands in the $3700-3200 \mathrm{~cm}^{-1}$ region, respectively at 1100 and $920 \mathrm{~cm}^{-1}$ strongly decrease or disappear. The silicate structure collapses; a broad, nearly symmetrical band is formed at $1030 \mathrm{~cm}^{-1}$. 
Simultaneously, the iron oxides attributed 540 and $580 \mathrm{~cm}^{-1}$ bands appear. Between $700-900^{\circ} \mathrm{C}$ crystallized hematite is formed, under reducing conditions magnetite also may form. The peak appearing at $572 \mathrm{~cm}^{-1}$ is due to $\mathrm{Fe}-\mathrm{O}$ vibration of iron oxides, but the exact nature of oxide can not be determined from the IR spectrum. Quartz and feldspar are usually present in pottery clays. Bands occurring at 462 and $514 \mathrm{~cm}^{-1}$ are assigned to mixed Si-O-Si and $\mathrm{O}-\mathrm{Si}-\mathrm{O}$ bending mode; the band at $470 \mathrm{~cm}^{-1}$ is due to $\mathrm{Si}-\mathrm{O}$ stretching. Sharp bands around 790 along with $695 \mathrm{~cm}^{-1}$ in all samples means the presence of quartz (Si-O).

Concerning the discussed samples, the relative weakness or the absence of characteristic $\mathrm{OH}$ bands around $3400 \mathrm{~cm}^{-1}$ and at $1600 \mathrm{~cm}^{-1}$ and the presence of a broad symmetry band centered around $1050 \mathrm{~cm}^{-1}$ in all cases means that all items were made of disordered clays and had to be fired above $600^{\circ} \mathrm{C}$. The presence and the intensity of the $3400 \mathrm{~cm}^{-1}$ and $1600 \mathrm{~cm}^{-1}$ peaks in this case depends on the rehydration processes taking place during the burial, in function of the environmental conditions and the ceramic composition and structure. Consequently, the most porous sample 5-2-1 shows the most intense hydroxyl peaks while they are almost totally missing from the spectrum of the most compact 5-2-3 probe.

Well resolved distinct peaks at 540 and $580 \mathrm{~cm}^{-1}$ reveal the presence of iron oxides, confirm that firing temperature was above $600^{\circ} \mathrm{C}$, and indicate that the sample was fired in oxidizing conditions, or at least that air has to be present from the beginning of cooling, which did enable (at least partly) the oxidation of the $\mathrm{Fe}$ content to $\mathrm{Fe}_{2} \mathrm{O}_{3}$ causing the red color of the pottery (air admission during cooling is still a common practice for coloration of the baked clays). The band around $540 \mathrm{~cm}^{-1}$ with a weak shoulder at $580 \mathrm{~cm}^{-1}$ in the sandwich structured items indicate that the sample is fired under reducing atmosphere, and air (oxygen) is admitted only at lower temperature (sandwich structure: inner black layer with outer red surface - sample 5-2-2).

The FTIR data and their possible interpretation, in concordance with the conclusions resulting from the $\mathrm{OM}$ and $\mathrm{XRD}$ analysis, confirm the presence of rehydrated amorphous glassy phases and the (re)apparition of $\mathrm{Fe}(\mathrm{OH})_{2}$ and/or $\mathrm{FeO}(\mathrm{OH})$. The presence of rehydrated clayish minerals is not excluded either, but their presence is of minimal importance.

\section{CONCLUSIONS}

The Tăşnad-Sere Roman potshard selection subjected to investigation is formed by five samples, chosen as the most representative ones regarding the studied archaeological context. 
Optical microscopy (OM), PXRD and FTIR spectral analysis are all in agreement when allowing the classification of the samples into two distinct groups and a transitional item.

The first group (samples 5-2-1 and 5-2-2) is formed by deliberate tempered ceramics fired at lower temperatures $\left(850-950^{\circ} \mathrm{C}\right)$. The temper in these cases seems to be partly rock fragments as vulcanites and crystalline rocks (granitoides and crystalline schists). These ceramics could not be used as cooking wares due to their hiatal fabric resulted from the production technology: the thermal dilatation differences appearing in the fine and coarse grain connection zones eventually would cause the break of the ceramic body.

The specimens of the second group (5-2-3 and 5-2-5) were produced from naturally tempered levigated clay paste fired at higher temperatures, resulting suitable cooking wares.

Sample 5-2-4 is transitional between the first and the second group, its mineralogical characteristics approaching it to the first group while technologically (modelling, firing temperature and conditions) matching with the second one.

The concordance of the results obtained by the OM, PXRD and FTIR spectroscopy analysis proves that the pursued archaeometric study is fairly efficient and reliable to categorize and roughly estimate the provenance of the artifacts even in case of a few-numbered selection.

However, for correct conclusions regarding the provenance of the raw materials used it is compulsive the completion of the investigation with element analysis (especially trace element characterization) of the investigated items as well as of the corresponding clayish soils in the neighbourhood of the site (in ancient pottery proximity of the outcrops could assure considerable economic savings). In order to correctly characterize the technical parameters (especially the firing conditions) applied to the production process it is necessary to proceed to supplementary determinations. (like thermoanalytical measurements). [23]

\section{EXPERIMENTAL}

In order to estimate the variability of the raw material sources and of the technology used, after a macroscopic characterization, the samples were investigated by petrographic-mineralogic thin layer microscopy (OM), PXRD analysis and FTIR spectroscopy. 
Polarized light microscopy was carried out in transmission mode on polished thin sections of $d=30 \mu \mathrm{m}$, with a Leitz Wetzlar Laborlux $11 \mathrm{Pol}$ microscope provided with Nikon Coolpix 995 camera.

PXRD analysis was performed using a BRUKER D8 Advance diffractometer (working parameters: $45 \mathrm{kV}, 45 \mathrm{~mA}$, Ni filtered Cu $\mathrm{K}_{\alpha}$ radiation collimated with Soller slits, step-scanning mode with $\Delta 2 \theta$ of $0.01^{\circ}$ steps, spectral pure $\mathrm{Al}_{2} \mathrm{O}_{3}$ internal standard). The sample support was uniformly coated with the finely pulverized ceramic sample (agate ball mill, mean particle diameter $<63 \mu \mathrm{m}$, PVC-based adhesive). The crystalline phase composition was determined using the MATCH! phase identification software and the IUCr/COD/AMCSD reference database [20-22].

FTIR absorption spectra were recorded on $\mathrm{KBr}$-pelletized samples (1 mg finely pulverized sample to $300 \mathrm{mg} \mathrm{KBr}$ ) in the $4000-400 \mathrm{~cm}^{-1}$ region with a JASCO FTIR-6100 spectrometer $\left(1.0 \mathrm{~cm}^{-1}\right.$ resolution).

\section{ACKNOWLEDGEMENTS}

The presented work is partly supported by the research project entitled "Transylvanian technical and cultural legacy. Industrial archaeology, archaeometallurgy and archaeometry" started by the Science and Engineering Department of the Research Institute of the Transylvanian Museum Society.

Our special thanks to Dr. Viorel Ciubotă and Róbert Gindele from the Satu Mare County Historical Museum for entrusting the samples.

\section{REFERENCES}

1. R. Martineau, A.V. Walter-Simonnet, B. Grobéty, M. Buatier, Archaeometry, 2007, 49, 23.

2. N. Iercoşan, , Studii şi Comunicări Satu Mare, 1994-1995, 11-12, 9.

3. C. Astalos, U. Sommer, C. Virag, Archaeology International, 2012-2013, 16, 47.

4. C. Virag, "Some aspects about the Neolithic settlement from Tasnad (Satu Mare County, Romania)", C. Virag, Ed., Proceedings of the Int. Conf. on Neolithic Cultural Phenomena in the Upper Tisa Basin, Satu Mare 2014, Editura Muzeului Sătmărean, 2015, 97.

5. *** "Cronica cercetărilor arheologice din România - campania 2004". XXXIX. Sesiune Naţională de Rapoarte Arheologice, Jupiter-Mangalia 2005, M.V. Angelescu, I. Oberlander-Târnoveanu, F. Vasilescu, Eds,: cIMeC - Institutul de Memorie Culturală, Bucuresti, ISBN 973-7930-03-7, 2005, 375. 
6. *** "Cronica cercetărilor arheologice din România - campania 2005", XL. Sesiune Naţională de Rapoarte Arheologice, Constanţa 2006, M.V. Angelescu, F. Vasilescu, Eds:, clMeC - Institutul de Memorie Culturală, Bucuresti, ISBN 973-7930-07-X, 2006, 359 and 479.

7. *** "Cronica cercetărilor arheologice din România - campania 2006", XLI. Sesiune Naţională de Rapoarte Arheologice, Tulcea 2006, M.V. Angelescu, F. Vasilescu, Eds:, cIMeC - Institutul de Memorie Culturală, Bucuresti, ISBN 978-973-87004-9-9, 2007, 365 and 477.

8. R.L. Folk, P.B. Andrews, D.W. Lewis, New Zealand Journal of Geology and Geophysics, 1970, 13, 937.

9. J. Kiuberis, A. Merkevičius, R. Juškènas, A. Kareiva, Materials Science, 2004, 10, 334.

10. G. Cultrone, C. Rodriguez-Navarro, E. Sebastian, O. Cazalla, M.J. de la Torre, European Journal of Mineralogy, 2001, 13, 621.

11. De Benedetto, G.E., Laviano, R., Sabbatini, L., Zambonin, P.G., Journal of Cultural Heritage, 2002, 3, 177.

12. S. Shoval, Optical Materials, 2003, 24, 117.

13. R. Venkatachalapathy, E. Manoharan, S. Dhanapandian, T. Sundareswaran, K. Deenadayalan, "Concepts of Biophysics", Kumar, A., Ed., APH (New Delhi). $2005,71$.

14. R. Palanivel, G. Velraj, Indian Journal of Pure and Applied Physics, 2007, 45, 501.

15. C. Manoharan, K. Veeramuthu, R. Venkatachalapathy, T. Radhakrishna, R. Ilango, Lithuanian Journal of Physics and Technical Sciences, 2008, 48, 195.

16. R. Ravisankar, S. Kiruba, P. Eswaran, G. Senthilkumar, A. Chandrasekaran, E-Journal of Chemistry, 2010, 7, S185.

17. R. Palanivel, U.R. Kumar, Romanian Journal of Physics, 2011, 56, 195.

18. S. Kramar, J. Lux, Materials and technology, 2015, 49, 503.

19. S. Kiruba, S. Ganesan, Spectrochimica Acta Part A: Molecular and Biomolecular Spectroscopy, 2015, 145, 594.

20. http://www.crystalimpact.com/match/

21. http://sdpd.univ-lemans.fr/cod

22. R.T. Downs, M. Hall-Wallace, American Mineralogist, 2003, 88, 247.

23. P. Comodi, S. Nazzareni, D. Perugini, M. Bergamini, Periodico di Mineralogia, 2006, 75, 95. 